\title{
Assessing the level and diagnostic accuracy of osteopontin and oral health status in periodontitis patients with/without Type-2 Diabetes Mellitus
}

Avaliação do nível e precisão do diagnóstico de Osteopontina e estado de saúde bucal em pacientes com periodontite com/sem Diabetes Mellitus tipo 2

Ahmed Makki Abdulrazzaq Al-Qarakhli ${ }^{1}$ (D), Firas Bashir Al-Taweel², Lubaba Abdulsamad Abdul Ameer², Saif sehaam saliem², Ali Abbas Abdulkareem²

1 - University of Anbar, College of Dentistry, Department of Oral Diagnosis, Anbar, Iraq.

2 - University of Baghdad, College of Dentistry, Department of Periodontics, Baghdad, Iraq.

\begin{abstract}
Objective: Investigating osteopontin (OPN) level in gingival crevicular fluid (GCF) of patients affected by periodontitis with or without Type-2 diabetes mellitus (T2DM). The aim of this study is to explore the possibility of OPN to differentiate between periodontal health and disease. Material and Methods: A total number of 36 participants seeking periodontal treatment were recruited in this pilot study and divided into three study groups. Periodontitis [systemically healthy participants with periodontitis (probing pocket depth) PPD (probing pocket depth) $\geq 4 \mathrm{~mm}$ ], periodontitis and poorly controlled type 2 diabetes mellitus (), and control (systemically and periodontally healthy periodontium) groups. Plaque index (PI), gingival index (GI) and PPD were examined. OPN level was measured in the GCF and analysed, using Enzyme-Linked Immunosorbent assay. Results: PI and GI were significantly higher in T2DM with periodontitis compared to periodontitis and control groups. Both periodontitis and P-T2DM groups showed significant increase in the OPN levels compared to control group $(\mathrm{p}<0.001)$. PPD showed the only significant positive association with OPN $(\mathrm{p}<0.001)$ compared to other clinical parameters. The receiver operating characteristics curve analysis demonstrated that OPN had higher area under the curve value (AUC: 0.95) in periodontitis compared to P-T2DM patients (AUC: 0.86). Conclusion: In periodontitis groups, clinical parameters were equally deteriorated together with significant increase in the expression of OPN compared to control. Furthermore, GCF levels of OPN were sensitive and specific enough to discriminate between health and periodontitis even with T2DM. This could introduce OPN to be as a candidate diagnostic biomarker of periodontal disease.
\end{abstract}

\section{KEYWORDS}

Osteopontin; Periodontitis; Bone loss; Type 2 Diabetes Mellitus.

\section{RESUMO}

Objetivo: Investigar o nível de osteopontina (OPN) no fluido gengival crevicular (GCF) de pacientes com periodontite com ou sem diabetes mellitus tipo 2 (T2DM). O objetivo deste estudo foi explorar a possibilidade da OPN diferenciar entre saúde e doença periodontal. Material e Métodos: No total, para este estudo piloto foram recrutados 36 participantes que estavam em busca de tratamento periodontal e divididos em três grupos de estudo: grupos periodontite [participantes sistemicamente saudáveis com periodontite (profundidade de sondagem) PPD $\geq 4 \mathrm{~mm}$ ], grupo periodontite e Diabetes Mellitus tipo 2 mal controlada (P-T2DM) e grupo controle (saudáveis sistemicamente e periodontalmente). Índice de placa (PI), índice gengival (GI) e PPD foram examinados. O nível de OPN foi medido no GCF e analisado usando o ensaio ELISA (Enzyme-Linked Immuno Sorbent Assay). Resultados: PI e GI foram significativamente maiores no T2DM com periodontite 
em comparação aos grupos com periodontite e controle. Os grupos com periodontite e P-T2DM apresentaram aumento significativo nos níveis de OPN em comparação ao grupo controle ( $\mathrm{p}<0,001)$. PPD mostrou a única associação positiva significativa com OPN $(\mathrm{p}<0,001)$ em comparação com outros parâmetros clínicos. A análise da curva de características operacionais do receptor demonstrou que OPN teve maior área sob o valor da curva (AUC: 0,95) na periodontite em comparação com pacientes com P-T2DM (AUC: 0,86). Conclusão: Nos grupos com periodontite, os parâmetros clínicos foram igualmente deteriorados juntamente com aumento significativo na expressão de OPN em comparação com o grupo controle. Além disso, os níveis de OPN no GCF foram sensíveis e específicos o suficiente para discernir entre saúde e periodontite, mesmo com T2DM. Isso poderia apresentar a OPN como um candidato a biomarcador diagnóstico de doença periodontal.

\section{PALAVRAS-CHAVE}

Osteopontina; Periodontite; Reabsorção óssea; Diabetes Mellitus Tipo 2.

\section{INTRODUCTION}

Periodontal disease is an inflammatory pathologic state of the tooth-supporting structures including the gingiva, alveolar bone, periodontal ligament and cementum. The periodontal disease is originated by bacterial infection, such as Porphyromonas gingivalis. This disease may continue in progression, reaching advance stages of periodontal destruction and bone loss. If left without the recommended non-surgical/ surgical treatment, it may lead to tooth mobility and subsequent tooth loss [1]. Periodontal disease has been reported to be associated with several systemic disease complications, such as, cardiovascular diseases [2], rheumatoid arthritis [3], chronic kidney disease [4], and diabetes mellitus (DM) [5].

DM is a metabolic disease, accompanied by hyperglycaemia, due to resistance to insulin. This disease causes a modern epidemic issue, affecting 463 million people worldwide according to the International Public Diabetic Federation in 2019. This number is expected to rise to 700 million by the year 2045 [6]. Intriguingly, $90 \%$ of those cases are type 2 diabetes mellitus (T2DM). T2DM has been confirmed as a pivotal risk factor for periodontal disease [7]. It increases the susceptibility of individuals to periodontal disease by twofold to fivefold [8]. Besides, a well-established relationship has been confirmed between the hyperglycaemic level and the severity of periodontal disease [9].

Osteopontin is one of the major noncollagenous extracellular bone matrix proteins, acting as a prime role in bone healing, remodelling and repair. It is proved to be secreted by pre-osteoblasts and macrophages. OPN then accumulated against resorbed bone surfaces forming OPN-rich cement line [9]. It is known to act as an adhesion and cell signalling protein for recruiting mature osteoblasts to the surface of the bone. OPN arranges early mineralisation stages and aids in the bonding of an old bone to a new one, forming an OPN cement line [10]. However, as one of the bone matrix proteins, OPN acts as a substrate for mediating osteoclasts' attachment to the bone at the clear zone, inducing bone resorption [10]. Moreover, OPN has another function, such as binding to mineral crystals and inhibiting their growth, which assists in bone remodelling. Thus, an increased expression of OPN may inhibit bone formation [11]. Interestingly, an increase in the expression of the OPN has been reported in the extracellular bone matrix of T2DM rats, compared to normal [12]. This could have destructive effects and may be linked to the inhibition of bone formation.

This study investigates the potential of OPN in discriminating between periodontal health and disease conditions. It was conducted through exploring the OPN level in GCF of periodontitis, periodontitis with T2DM (P-T2DM) and control groups of participants.

\section{MATERIALS AND METHODS}

\section{Study design}

This study was a case-control observational study. The participants were those patients who were referred for periodontal treatment at the teaching hospital, Department of Periodontics, College of Dentistry, University of Baghdad. The study was started in August 2019 and finished in October 2019. The approval study conduction was granted by the relevant ethics committee (Ref.61 at 03/07/2019). 


\section{Study population and clinical examination}

Thirty-six participants were equally distributed into three groups namely, periodontitis, (P-T2DM), and control participants.

1- The control group includes systemically and periodontally healthy periodontium participants [absence of bleeding and probing pocket depth $(\mathrm{PPD}) \leq 3 \mathrm{~mm}$;

2- Periodontitis group includes systemically healthy participants but having periodontitis (PPD $\geq 4 \mathrm{~mm}$ );

3- P- T2DM group includes participants having periodontitis (PPD $\geq 4 \mathrm{~mm}$ ) and poorly controlled diabetes mellitus.

Participants were recruited in this study, according to application of inclusion and exclusion criteria. Signing an informed consent form to participate in this study. Periodontal health was defined by presence of probing PPD $\leq 3 \mathrm{~mm}$, no bleeding on probing, and loss of attachment due to periodontal disease. While the definition of periodontitis followed the criteria of the Centres for Disease Control and Prevention/American Academy of Periodontology [13].

The inclusion criteria were:

1- The controls with healthy periodontium and free of any systemic disease(s);

2- For study groups, $\mathrm{PPD} \geq 4 \mathrm{~mm}$;

3- Poorly controlled hyperglycaemia with $\mathrm{PPD} \geq 4 \mathrm{~mm}$;

4- Participants having only diabetes mellitus but no other systemic diseases;

5- Participants' age is between 35-65 years.

Exclusion criteria:

1- Current and former smokers;

2- Pregnant and lactating women;

3- Controlled diabetes mellitus, those with fasting plasma glucose $(\leq 126 \mathrm{mg} / \mathrm{dl})$;

4- History of antibiotic/non-steroidal antiinflammatory drugs intake in the last 3 months;

\section{5- Not willing to participate.}

Poorly controlled T2DM participants were identified first by those who never instructed to have a self-monitoring of blood glucose. In addition, they were not regularly supervised by their physicians or taking medications. This was confirmed by measuring fasting plasma glucose $(\geq 126 \mathrm{mg} / \mathrm{dl}$ ) or a random plasma glucose level ( $\geq 200 \mathrm{mg} / \mathrm{dl}$ ).

The periodontal examination was performed by using Williams periodontal probe to measure different indices such as plaque index (PI), gingival index (GI), and PPD at six sites per tooth.

\section{Collection of gingival crevicular fluid}

Gingival crevicular fluid (GCF) samples were collected from periodontal pockets for the periodontitis groups. In healthy control group, the mesiobuccal aspects of Ramfjord teeth were selected as representatives for GCF collection [14]. The collection of GCF was conducted after removal of supragingival deposits. Briefly, the collection sites were gently washed, using air-syringe to remove saliva and insertion of cotton roll around the collection sites. The supragingival area was wiped with clean gauze before insertion of the periodontal filter paper strips (ORALFLOW, NY, USA). A paper strip was gently placed $1-2 \mathrm{~mm}$ into the sulcus/pocket until light resistance was felt, held in place for 30 seconds, after careful isolation and dryness [14]. Samples were immediately transferred to Eppendorf tube containing $200 \mu \mathrm{L}$ of phosphate-buffered saline (PBS) and stored at $-80^{\circ} \mathrm{C}$. The process was repeated after $15 \mathrm{~min}$ when contamination with blood or saliva was detected.

\section{Determination of OPN levels in GCF using Enzyme Linked-Immunosorbent Assay (ELISA)}

OPN was quantified using Human Osteopontin YH ELISA kit (Shanghai YEHUA Biological Technology Co., Ltd, China). Samples were thawed to room temperature and centrifuged at $2500 \mathrm{rpm}$ for $20 \mathrm{~min}$. Assaying level of OPN in GCF samples was carried out following instruction manual provided by the manufacturer. Optical density values were measured using a spectrophotometry plate reader (BioTek, USA) at $450 \mathrm{~nm}$. The amount of OPN was quantified by plotting the standard samples as a reference standard curve. The experiment was performed in triplicate and the results were expressed in $\mathrm{ng} / \mathrm{mL}$.

\section{Examiners' calibration}

The calibration for recording PI, GI, PPD and GCF collection was carried out on four volunteers between senior in periodontics and two of the 
researchers. The calibration was repeated twice until an agreed value of $80 \%$ was reached.

\section{Statistical analysis}

Continuous data were expressed as means \pm standard deviation. The statistical significance of differences between multiple groups was calculated, using a one way-ANOVA test followed by Tukey's multiple comparisons post-hoc, while t-test was used for comparing PPD. Receiver operating characteristic (ROC) curves and the area under the ROC curve (AUC) were used to determine sensitivity and specificity of OPN to differentiate between health and disease states. Pearson ( $r$ ) correlation coefficient test was utilized to investigate the association of clinical parameters with OPN. A p value of $\leq 0.05$ was considered as a statistically significant difference. Analysis was performed by using GraphPad Prism software (version 8, USA).

\section{RESULTS}

A total of 36 patients ( 27 male and 9 female) were recruited in this study who were equally distributed among the groups (12 patient each) with 1:1:1 ratio. Mean and range of age, and gender distribution for each group together with descriptive statistics of the clinical parameters are illustrated in Table I.

Analysis of clinical parameters showed that PI and GI scores for P-T2DM were significantly higher than the other groups (Figure 1A, B). However, no significant difference was observed in PPD between periodontitis and P-T2DM groups (Figure 1C). OPN level in GCF was significantly

Table I - Demographic and clinical characteristics of the patients

\begin{tabular}{lccc} 
& Control & Periodontitis & P-T2DMף \\
\hline Age $^{\S}$ & $49.83 \pm 8.23$ & $46.50 \pm 9.42$ & $50.83 \pm 7.59$ \\
\hline Age range & $36-60$ & $34-65$ & $37-60$ \\
Gender $^{\dagger}$ & & & \\
Male & 9,25 & $8,22.2$ & $10,27.8$ \\
\hline Female & $3,8.3$ & $4,11.1$ & $2,5.6$ \\
Study sample $(n)$ & 12 & 12 & 12 \\
\hline Clinical parameters & & & \\
PI & $1.51 \pm 0.39$ & $1.48 \pm 0.36$ & $2.05 \pm 0.18$ \\
GI & $0.90 \pm 0.41$ & $1.29 \pm 0.38$ & $2.28 \pm 0.27$ \\
PPD & & $4.33 \pm 0.65$ & $4.83 \pm 0.72$
\end{tabular}

9 Periodontitis with type 2 diabetes mellitus; ${ }^{\dagger}$ Frequency, percentage; $\S$ Mean $\pm \mathrm{SD}$ lower in association with control group as compared to periodontitis and P-T2DM groups (Figure 2). The limit of detection (LOD) for OPN values was between $(3.885-6.448 \mathrm{ng} / \mu \mathrm{L})$. ROC curve and the AUC analysis for OPN for periodontitis and P-T2DM are shown in Figure 3. The AUC value for OPN in periodontitis group had higher value $(0.9583)$ than P-T2DM group (AUC: 0.8611).

Regardless of the group type, the overall correlation showed a significant and positive correlation $(p<0.001)$ between OPN and PPD. There was no correlation with PI nor with GI. However, this correlation was not significant between these indices of individual groups with OPN (Table II).

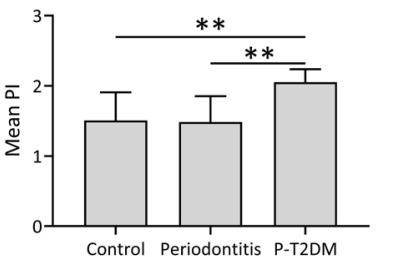

A

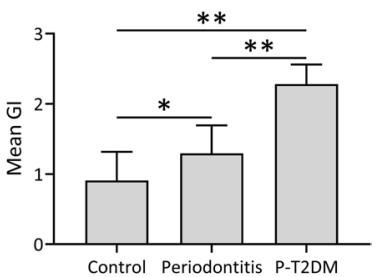

B

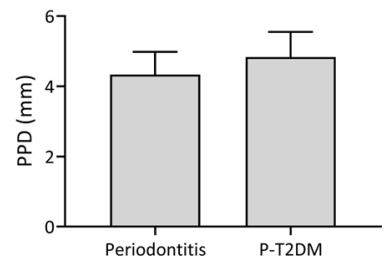

C

Figure 1. $\mathrm{PI}(\mathrm{A})$ and $\mathrm{Gl}(\mathrm{B})$ of $\mathrm{P}-\mathrm{T} 2 \mathrm{DM}$ were significantly higher than control and periodontitis alone groups. Measurements of PPD did not show any significant different between periodontitis alone and $\mathrm{P}-\mathrm{T} 2 \mathrm{DM}(\mathrm{C}) .{ }^{*} \mathrm{P}<0.05,{ }^{*} \mathrm{P}<0.001$

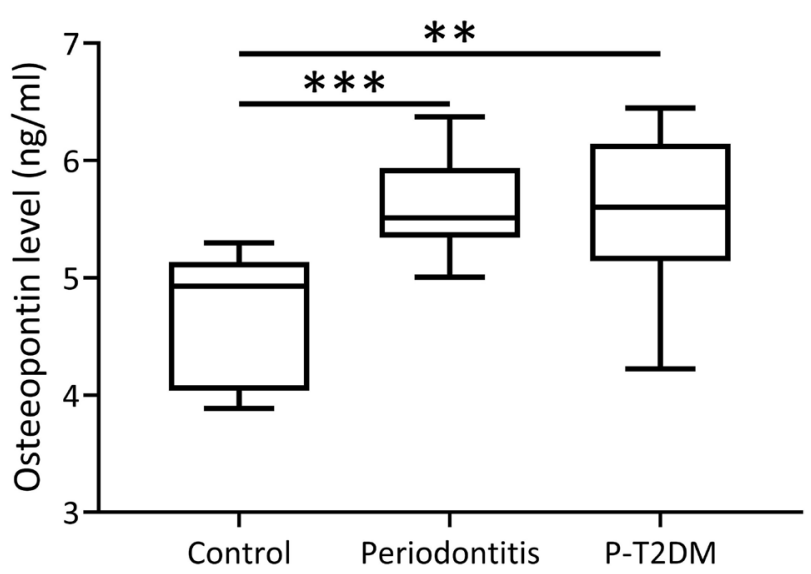

Figure 2. OPN levels measured in GCF were significantly higher in periodontitis alone and P-T2DM than control group. Boxes represent interquartile range, lines represent median values, and whiskers show the minimum and maximum values for each group. ${ }^{\star *} \mathrm{P}<0.003,{ }^{* * *} \mathrm{P}<0.0001$. 
Table II - The correlation between OPN and clinical parameters relative to individual groups

\begin{tabular}{|c|c|c|c|c|}
\hline Groups & Variable correlation & $\begin{array}{l}\text { correlation coefficient } \\
\text { (r) }\end{array}$ & P-value* & Significance \\
\hline \multirow{3}{*}{ Control } & OPN and PI & 0.04 & 0.88 & NS \\
\hline & OPN and GI & -0.1 & 0.75 & NS \\
\hline & OPN and PPD & 0.03 & 0.91 & NS \\
\hline \multirow{3}{*}{ Periodontitis } & OPN and PI & 0.06 & 0.83 & NS \\
\hline & OPN and GI & -0.1 & 0.75 & NS \\
\hline & OPN and PPD & -0.2 & 0.52 & NS \\
\hline \multirow{3}{*}{ P-T2DM } & OPN and PI & 0.04 & 0.88 & NS \\
\hline & OPN and GI & -0.09 & 0.75 & NS \\
\hline & OPN and PPD & 0.04 & 0.88 & NS \\
\hline
\end{tabular}

*Significant difference at $\mathrm{P}<0.05$ using Pearson's correlation test; Control: systemically and periodontally heathy; Periodontitis: systemically healthy and having periodontal disease; P-T2DM: having periodontitis (PPD $\geq 4 \mathrm{~mm}$ ) and systemically involved by poorly controlled type 2 diabetes mellitus.

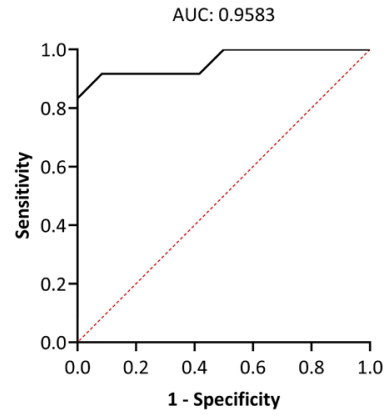

A

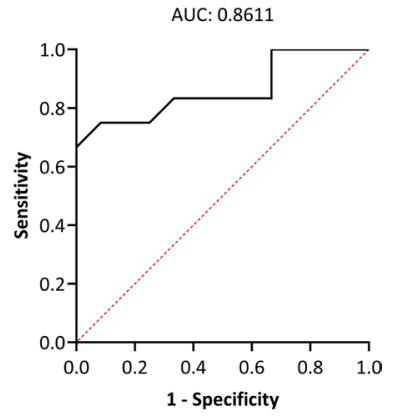

B

Figure 3. Receiver operating characteristic (ROC) curves and the area under the ROC curve (AUC) values for the OPN in periodontitis group (A) and P-T2DM (B). Although AUC of periodontitis alone group was higher than P-T2DM (0.9583 and 0.8611 respectively). However, both curves showed the potential of OPN to discriminate periodontal health from disease despite systemic condition.

\section{DISCUSSION}

OPN has been reported as a secreted protein, involved in a variety of physio-pathological activities. OPN regulates several cellular activities, such as tissue remodelling, immune regulation and bio-mineralization [9]. In addition, the development of inflammatory adipose tissue and insulin resistance is potentially mediated by OPN [15]. This point may have a great insight for the pathogenesis of DM. Possibly, through upregulation by several inflammatory cytokines which are known to be elevated in T2DM [16]. Both periodontitis and DM may share a common inflammatory cyclical association. A bidirectional relationship was suggested to which OPN could be involved [17]. Having this in consideration, this study was conducted to explore the OPN level in the GCF and various clinical periodontal parameters of the control healthy, periodontitis, and P-T2DM participants.

For oral hygiene analysis, the result showed that there was a significant increase in the PI and GI in P-T2DM compared to periodontitis and healthy participants. This is in agreement with a previous study that showed a similar pattern [18]. This could be attributed to the attitude level of T2DM with periodontitis participants towards maintaining their oral hygiene measures, such as tooth brushing being lower than other groups. Altered attitude of patients with diabetes mellitus could be related to the fact that diabetes is a quality of life-compromising disease. It has a negative personal factor affecting the host defense as well as increasing inflammation [19].

Although the results demonstrated that the PPD scores increased in P-T2DM participants than periodontitis alone, they were not significant. This is supported by a previous meta-analysis [20]. Several factors have been proposed to have a role in the periodontal destruction and increased PPD in diabetes. These include; altered polymorphonuclear cell function, host defenses [21] and changes in tissue homeostasis by a well-established microangiopathic influence. This is associated with an increase in collagen degradation via increased matrix metalloproteinases production [22]. In addition, hyperglycemic changes in the subgingival microenvironment, may directly favour the cultivation of the most dominant pathogenic bacterial species [23], such as Porphyromonas gingivalis [24], or indirectly by altering the host response. All of these possible pathways may independently or synergistically act to progressively destruct the periodontal tissues. 
This is presented by an increase in the PPD in this study.

OPN level in the GCF was significantly higher in P-T2DM and periodontitis compared to control participants. Within this study, this pattern of difference shows a great similarity to the level of PPD between all groups. This indicates that there is a link between increase in OPN expression and PPD. It was supported by the significant correlation which is found to be moderate between OPN and PPD in all groups regardless of the group types. However, there was no correlation between OPN and all periodontal parameters, including PPD when separately calculated in each group. This might be related to the relatively low sample size in each group.

To the best of our knowledge, limited studies have investigated the OPN level in the GCF of the healthy control, which was lower compared to those who had periodontitis [25]. The later groups had the highest OPN expression beside a positive correlation with the clinical attachment loss and pocket depth in pre-periodontal treatment [26]. This was consistent with the results of our study. However, there is no single research that measured OPN value in the GCF of T2DM with periodontitis.

OPN has been found to bind with the bone mineral crystals and increase expression, which is suggested to inhibit bone formation $[9,11]$. It anchors the osteoclasts binding to the clear zone of the bone, inducing bone resorption [10]. Increased PPD in P-T2DM in our study may indicate a higher bone resorption at the crestal part than formation with clinical attachment loss. This could be explained by microbial and cellular interactions related to periodontitis and/or diabetes. This could exacerbate the severity of the bone loss. Thus, the increase in the PPD in P-T2DM group could be influenced by the increased expression of the OPN, which is supported by our results. This suggests that OPN could act as an important osteogenic marker in the pathological pathway of T2DM to exacerbate periodontal disease. However, the phosphorylated status of OPN has shown to play a key role in the biomineral regulation function [27]. This notion was supported by the ROC and AUC analysis. They showed that the accuracy of OPN in P-T2DM to differentiate between periodontal health and disease was lower than that of the periodontitis group.
Nevertheless, OPN in both periodontitis groups demonstrated excellent potential as a predictor of periodontal destruction, including increase in the periodontal pocket depth. The interest in developing chair-side techniques based on a single or combination of biomarkers has increased in the last decades [28]. Currently, active form of matrix metalloproteinase-8 (MMP-8) is available commercially as Point-of-Care. Chair-side tests could effectively predict, diagnose, and monitor the progression of periodontal/peri-implant diseases. However, MMP-8 accuracy was found to be altered in response to local factors and systemic conditions [29]. Thus, the need to a new biomarker is a paramount. In the current study OPN has been found to have accuracy to differentiate between health and disease, and it may be used as a potential predictor of periodontal diseases. On the other hand, the effects of local and systemic conditions of OPN are not addressed yet. Thus, further studies are required to explore these factors.

This study was mainly limited by the small sample size. In addition, it is only provided a potential association of OPN with periodontitis, but not cause-effect explanation. Therefore, a larger-scale and long-term prospective studies are required. This may illustrate changes at the host cell/microbiological levels, or even the phosphorylated state of OPN that play a functional role in bone resorption/formation.

The main role of OPN in the periodontium is not fully identified yet. Herein, identifying this point is vital to understand the increase in the OPN in GCF and its consequences on severe bone loss in T2DM with periodontitis participants.

\section{CONCLUSIONS}

The results of this study suggest that OPN levels in GCF could differentiate between health and periodontitis situations even if the subject is affected by T2DM. This may shed a light to consider OPN as a candidate for a possible biomarker of diagnostic prediction among health and disease.

\section{Acknowledgments}

We would like to thank Dr. Ali Hassan Hayawi for his kind assistance to achieve of this paper. 


\section{Conflict of Interest}

Authors declare no conflicts of interest.

\section{Funding}

None.

\section{Regulatory Statement}

This study was conducted after obtaining approval from ethics committee (Ref. 61 at 03/07/2019) in accordance with Helsinki declaration of human research

\section{REFERENCES}

1. Nanci A, Bosshardt DD. Structure of periodontal tissues in health and disease. Periodontol 2000. 2006:40(1):11-28. http://dx.doi. org/10.1111/j.1600-0757.2005.00141.x. PMid:16398683.

2. Humphrey LL, Fu R, Buckley DI, Freeman M, Helfand M. Periodontal disease and coronary heart disease incidence: a systematic review and meta-analysis. J Gen Intern Med. 2008:23(12):2079-86. http://dx.doi.org/10.1007/s11606-008-0787-6. PMid:18807098.

3. Detert J, Pischon N, Burmester GR, Buttgereit F. The association between rheumatoid arthritis and periodontal disease. Arthritis Res Ther. 2010;12(5):218. http://dx.doi.org/10.1186/ar3106. PMid:21062513

4. Chambrone L, Foz AM, Guglielmetti MR, Pannuti CM, Artese HP, Feres $M$, et al. Periodontitis and chronic kidney disease: a systematic review of the association of diseases and the effect of periodontal treatment on estimated glomerular filtration rate. J Clin Periodontol. 2013;40(5):443-56. http://dx.doi.org/10.1111/ jcpe.12067. PMid:23432795

5. Mealey BL, Ocampo GL. Diabetes mellitus and periodontal disease. Periodontol 2000. 2007:44(1):127-53. http://dx.doi. org/10.1111/j.1600-0757.2006.00193.x. PMid:17474930

6. Saeedi P, Petersohn I, Salpea P, Malanda B, Karuranga S, Unwin $\mathrm{N}$ et al. Global and regional diabetes prevalence estimates for 2019 and projections for 2030 and 2045. 9th ed. Bruxelas: International Diabetes Federation Diabetes Atlas; 2019.

7. Chávarry NG, Vettore MV, Sansone C, Sheiham A. The relationship between diabetes mellitus and destructive periodontal disease: a meta-analysis. Oral Health Prev Dent. 2009;7(2):107-27. PMid:19583037.

8. Preshaw PM. Periodontal disease and diabetes. J Dent. 2009;37(8):S575-7. http://dx.doi.org/10.1016/j.jdent.2009.05.019. PMid:19497655.

9. Bissett S, Pumerantz A, Preshaw P. Periodontal disease and diabetes. J Diabetes Nurs. 2015:19:134-40.

10. McKee MD, Pedraza CE, Kaartinen MT. Osteopontin and wound healing in bone. Cells Tissues Organs. 2011;194(2-4):313-9. http:// dx.doi.org/10.1159/000324244. PMid:21576907.

11. Pedraza CE, Nikolcheva LG, Kaartinen MT, Barralet JE, McKee MD. Osteopontin functions as an opsonin and facilitates phagocytosis by macrophages of hydroxyapatite-coated microspheres: implications for bone wound healing. Bone. 2008:43(4):708-16. http://dx.doi.org/10.1016/j.bone.2008.06.010. PMid:18656563.

12. Colombo JS, Balani D, Sloan AJ, Crean SJ, Okazaki J, Waddington RJ. Delayed osteoblast differentiation and altered inflammatory response around implants placed in incisor sockets of type 2 diabetic rats. Clin Oral Implants Res. 2011:22(6):578-86. http:// dx.doi.org/10.1111/j.1600-0501.2010.01992.x. PMid:21054552.

13. Eke PI, Page RC, Wei L, Thornton-Evans G, Genco RJ. Update of the case definitions for population-based surveillance of periodontitis.
J Periodontol. 2012;83(12):1449-54. http://dx.doi.org/10.1902/ jop.2012.110664. PMid:22420873.

14. Wassall RR, Preshaw PM. Clinical and technical considerations in the analysis of gingival crevicular fluid. Periodontol 2000. 2016;70(1):6579. http://dx.doi.org/10.1111/prd.12109. PMid:26662483.

15. Nomiyama T, Perez-Tilve D, Ogawa D, Gizard F, Zhao Y, Heywood $E B$, et al. Osteopontin mediates obesity-induced adipose tissue macrophage infiltration and insulin resistance in mice. J Clin Invest. 2007;117(10):2877-88. http://dx.doi.org/10.1172/JCl31986. PMid:17823662.

16. Nakamachi T, Nomiyama T, Gizard F, Heywood EB, Jones KL, Zhao $Y$, et al. PPARalpha agonists suppress osteopontin expression in macrophages and decrease plasma levels in patients with type 2 diabetes. Diabetes. 2007:56(6):1662-70. http://dx.doi. org/10.2337/db06-1177. PMid:17360982

17. lacopino AM. Periodontitis and diabetes interrelationships: role of inflammation. Ann Periodontol. 2001;6(1):125-37. http://dx.doi. org/10.1902/annals.2001.6.1.125. PMid:11887455.

18. Gupta N, Gupta ND, Garg S, Goyal L, Gupta A, Khan S, et al. The effect of type 2 diabetes mellitus and smoking on periodontal parameters and salivary matrix metalloproteinase-8 levels. J Oral Sci. 2016;58(1):1-6. http://dx.doi.org/10.2334/josnusd.58.1. PMid:27021533.

19. Clarke NG, Hirsch RS. Personal risk factors for generalized periodontitis. J Clin Periodontol. 1995;22(2):136-45. http://dx.doi. org/10.1111/j.1600-051X.1995.tb00125.x. PMid:7775670.

20. Khader YS, Dauod AS, El-Qaderi SS, Alkafajei A, Batayha WQ. Periodontal status of diabetics compared with nondiabetics: a meta-analysis. J Diabetes Complications. 2006;20(1):59-68. http:// dx.doi.org/10.1016/j.jdiacomp.2005.05.006. PMid:16389170.

21. Kornman KS, Page RC, Tonetti MS. The host response to the microbial challenge in periodontitis: assembling the players. Periodontol 2000. 1997;14(1):33-53. http://dx.doi. org/10.1111/j.1600-0757.1997.tb00191.x. PMid:9567965.

22. Kumar MS, Vamsi G, Sripriya R, Sehgal PK. Expression of matrix metalloproteinases (MMP-8 and -9) in chronic periodontitis patients with and without diabetes mellitus. J Periodontol. 2006:77(11):18038. http://dx.doi.org/10.1902/jop.2006.050293. PMid:17076603.

23. Hintao J, Teanpaisan R, Chongsuvivatwong V, Ratarasan C, Dahlen G The microbiological profiles of saliva, supragingival and subgingival plaque and dental caries in adults with and without type 2 diabetes mellitus. Oral Microbiol Immunol. 2007;22(3):175-81. http://dx.doi. org/10.1111/j.1399-302X.2007.00341.x. PMid:17488443.

24. Ojima M, Takeda M, Yoshioka H, Nomura M, Tanaka N, Kato T, et al. Relationship of periodontal bacterium genotypic variations with periodontitis in type 2 diabetic patients. Diabetes Care. 2005;28(2):433-4. http://dx.doi.org/10.2337/diacare.28.2.433. PMid:15677809.

25. Tarallo F, Chimenti C, Paiella G, Cordaro M, Tepedino M. Biomarkers in the gingival crevicular fluid used to detect root resorption in patients undergoing orthodontic treatment: a systematic review. Orthod Craniofac Res. 2019;22(4):236-47. http://dx.doi. org/10.1111/ocr.12329. PMid:31207100

26. Sharma CG, Pradeep AR. Plasma and crevicular fluid osteopontin levels in periodontal health and disease. J Periodonta Res. 2007:42(5):450-5. http://dx.doi.org/10.1111/j.16000765.2007.00968.x. PMid:17760823

27. Christensen B, Kläning E, Nielsen MS, Andersen MH, Sørensen ES. C-terminal modification of osteopontin inhibits interaction with the $\alpha$ V $\beta 3$-integrin. J Biol Chem. 2012;287(6):3788-97. http:// dx.doi.org/10.1074/jbc.M111.277996. PMid:22179617.

28. Srivastava N, Nayak PA, Rana S. Point of care- a nove approach to periodontal diagnosis-a review. J Clin Diagn Res. 2017;11(8):ZE01-ZE06. http://dx.doi.org/10.7860/ JCDR/2017/26626.10411. PMid:28969294

29. Heikkinen AM, Sorsa T, Pitkäniemi J, Tervahartiala T, Kari K Broms $U$, et al. Smoking affects diagnostic salivary periodontal disease biomarker levels in adolescents. J Periodontol. 2010;81(9):1299-307. http://dx.doi.org/10.1902/jop.2010.090608. PMid:20450405 


\section{Ahmed Makki Abdulrazzaq Al-Qarakhli}

(Corresponding address)

University of Anbar, College of Dentistry, Department of Oral Diagnosis, Anbar, Iraq

Email: Den.ahmed.maki@uoanbar.edu.iq

Date submitted: 2021 April 22

Accepted submission: 2021 September 09 